\title{
The Moderating Role of Self-Esteem and Job-Related Anxiety on the Emergence of Dysfunction in Vocational Mentoring and Its Effects on Performance Reports and Career Progress Expectations
}

\author{
Ethlyn A. Williams \\ Florida Atlantic University \\ Terri A. Scandura \\ University of Miami \\ Stephanie L. Castro \\ Florida Atlantic University
}

We explore the role that self-esteem and job-related anxiety play in the emergence of dysfunctional (negative) relations in mentoring and its outcomes. A study with 189 proteges reported that functional vocational mentoring in a mentorship was negatively related to reports of dysfunction in vocational mentoring (DVM), however, this association became positive for individuals reporting low self-esteem. The relationship that DVM had with performance and career expectations was moderated by job-related anxiety -negative outcomes under high anxiety conditions and a positive outcome for performance under low anxiety. Thus, further work on the emergence and effects of dysfunction (negative) mentoring relations appears warranted.

Keywords: mentoring, dysfunction, self-esteem, anxiety, performance, career progress

\section{INTRODUCTION}

Existing research on mentoring highlights the benefits obtained by protégés from this developmental relationship (Allen, Eby, Poteet, Lima, \& Lentz, 2004; Tong \& Kram, 2013). Mentoring relationships involve an individual with more experience providing career (and often personal) assistance to a less experienced person (or protégé; Haggard, Dougherty, Turban, \& Wilbanks, 2011). Mentoring is associated with higher subordinate career satisfaction, career mobility, salary, and performance (Dreher \& Ash, 1990; Tong \& Kram, 2013). Although reported outcomes are often positive, mentoring research has explored processes and outcomes that emerge when a relationship becomes negative or dysfunctional, such as high levels of turnover intent (Eby, Butts, Durley, Ragins, 2010; Eby, Butts, Lockwood, \& Simon, 2004; Eby, Durley, Evans, \& Ragins, 2008).

While the incidence of dysfunction in mentorship is not high (Scandura, 1998), research in the social psychology literature reminds us that relationships are generally characterized by positive and negative 
interactions or thoughts about the relationship (Lee, Thomas, Martin \& Guillaume; Wood \& Duck, 1995). Scandura (1998) and Eby et al. (2004; 2010) suggest that poor mentoring can have destructive consequences for the protégé. Dysfunction occurs when one or both parties are not benefiting from the relationship and there is distress as a result of this situation (Scandura, 1998). More specifically, dysfunction in the vocational arena of mentoring relationships is reflected in feelings of regret and career damage (Scandura, 1998).

Brooks \& Highhouse, (2006) note that "familiarity breeds ambivalence", and suggest that factors such as frequency of interaction, the length of time spent in a relationship, and interaction across multiple domains (e.g., of work and life) may allow negative aspects to arise and become obvious. This relational ambivalence refers to "... members who are sources of both positivity and negativity." Given the gap identified in research on moderators (Rothman, Pratt, Rees, \& Vogus, 2017) of the experience of negative mentoring and between such negative experiences and outcomes that result, the present study examines the potential role that protégé self-esteem and job-related anxiety play in the emergence of negative mentoring experiences and also the role of job-anxiety in outcomes reported. Self-esteem is one of "... the best dispositional predictors of job satisfaction and job performance" (Judge \& Bono, 2001, p. 80). Judge, Locke, and Durham (1997) identified self-esteem as the most fundamental manifestation of core selfevaluations. Self-esteem describes the overall value that an individual places on himself/herself. Anxiety is at times context-related (Raffety, Smith, \& Ptacek, 1997), job-related anxiety describes tensions experienced that are brought on by job requirements and results in an unpleasant emotional state that has negative consequences. Research suggests that those with low self-esteem and high anxiety/workplace stress would report more relationship problems (Dodgson \& Wood, 1998; Eby et al., 2004). We integrate the fields of mentoring, self-esteem, and job-related anxiety in the workplace since this research has implications that are relevant to other settings including education, troubled teens, and minority groups.

The purpose of the current research is first, to examine the occurrence of dysfunction in vocational mentoring and the role of self-esteem and job-related anxiety second, to examine the extent to which jobrelated anxiety affects the way that the experience of dysfunction in vocational mentoring affects performance and career outcomes. We, therefore, examine positive and negative experiences in the same mentorship to explain the influences of positive perceptions on the perceptions of negative mentoring and its outcomes.

\section{BACKGROUND}

The focus of the current research is on vocational mentoring, characterized as one element of mentoring relationships that might be influenced by both positive and negative experiences. Negative mentoring in the vocational arena might be experienced through spoiling, which possibly involves good intent toward another (Eby \& McManus, 2004; Scandura, 1998). Some perceived betrayal may have occurred and there is regret about having invested in the relationship (Scandura, 1998). We, therefore, employ the characteristics of spoiling to reflect dysfunction in vocational mentoring (Scandura, 1998). Spoiling reflects feelings of betrayal and regret and might also reflect self-absorption (Eby, McManus, Simon, \& Russell, 2000) and its effects because the mentor places his concerns above those of the protégé (Eby, et al., 2004; Eby et al., 2008). You might ask why individuals stay in relationships that produce ambivalent feelings; Bushman and Holt-Lunstad (2009) note that ambivalent relationships (in which there are positive and negative experiences) are often maintained because of commitment to the relationship; the basis for the establishment of mentorships. Given that these relationships will likely be maintained in the context of mentorship, we seek to understand the association between positive and negative experiences, how job anxiety and self-esteem moderate the occurrence of negative experiences, and how job-related anxiety moderates the outcomes of negative vocational mentoring.

Job-related anxiety is expected to have a strong effect on dysfunction in mentoring. Anxiety reflects an awareness that the work environment is having a negative effect on the psychological and physiological functioning of the individual (Margolis \& Kroes, 1974). Scandura \& Williams (2004) called for research that examines the way in which a negative climate within an organization results in negative outcomes in 
the presence of mentoring. Job-related anxiety may be a reflection of a negative climate (McClure, Bartz, \& Lydon, 2013), and thus important in the study of dysfunctional mentoring.

Our research also focuses on the importance of the self-concept for the development of mentoring relationships and reports of relational problems. Self-esteem has been examined in research on antisocial behavior and other relational problems (Douglas \& Martinko, 2001). The self-concept, and in particular self-esteem, has been described as important for secure attachment at work (Mikulincer, Shaver, Bar-On \& Ein-Dor, 2010). Neusdat, Chamorro-Premuzic, \& Furnham, 2006). Attachment theory has examined infant through adult relationships, and it helps us understand the importance of relationships for those in adolescent, school, and work situations. Adult attachment theory focuses on the individual's tendency to search for and maintain relationships with individuals they view as able to provide security (Berman \& Sperling, 1994), with important relationships associated with greater commitment (Bersheid \& Reis, 1998). Mentoring relationships contain interpersonal bonds that reflect aspects of attachment (Ainsworth, 1989).

Regardless of one's attachment style tendency (to feel secure, to avoid, or to be anxious in relationships) the types of interactions that occur in mentorships can be characterized by positivity (functional support) and negativity (negative exchanges or feelings). Proteges who report job-related anxiety or low self-esteem will likely benefit less from mentoring and might be more likely to experience distress at work in response to negative aspects of mentoring. For example, DeJanasz and Sullivan (2004) discuss how critical support from a mentor is for the faculty career; they also note that "graduate students are expected to attach themselves early and tightly to individual professors" (p. 265). In more traditional work contexts proteges are expected to maintain the mentorship over an extended period (Allen et al., 2004).

\section{THEORY AND HYPOTHESES}

\section{Mentoring Experiences and Outcomes}

Previous research on traditional mentoring indicates that protégés benefit from a relationship with a more experienced individual who provides career and psychosocial support (Kram, 1985). This research focuses on vocational support which describes actions that enhance advancement in the organization (Kram, 1985; Ensher, Thomas \& Murphy, 2001) by helping the protégé learn their jobs, receive exposure, and promotions (Allen, Eby, Poteet \& Lentz, 2004). Dysfunctional or negative mentoring is related to higher stress and turnover intentions, lower job satisfaction, depression, and job withdrawal (Eby et al., 2004; 2008). Relational dysfunction may often characterize a decline in the relationship (Kram, 1985).

The experience of dysfunction may emerge when the cultivation phase is truncated due to problems in the relationship since there may be conflicting perceptions and expectations of the relationship (Viator \& Pasewark, 2005). For example, in spoiling, changes occur in the relationship that might make a relationship that might have been previously satisfying become disappointing. Spoiling involves vocational issues with good intent - with the absence of malice or betrayal, and involves regret. Thus, while both parties might enter the mentorship with high expectations and possibly even experience initial success, some relationships may have problems that reflect negative interactions and feelings of regret on the part of the protégé. Mentoring attachment reflects devoted loyalty (a mode of attachment), but it can also be a source of tension with ambivalence evident when expectations are mismatched - for example when the protégé feels inhibited. Commitment refers to the intention of staying in the relationship while loyalty is an avenue for realizing that intention (Oglensky, 2008). Positive aspects of the relationship are likely to influence perceptions of negative mentoring with the benefits reaped during the development of the relationship helping shape the perception of dysfunction. We, therefore, expect that when there are higher levels of vocational support reported by the protégé, the less likely he or she will be to report dysfunctions in the receipt of vocational support. Thus,

Hypothesis 1: Reports of vocational support in a mentoring relationship will be negatively related to reports of dysfunction in vocational mentoring in the same relationship. 


\section{Dysfunction in Vocational Mentoring and Protégé Self-Esteem}

Bowlby (1988) noted that attachment characterizes human relationships, with individuals vacillating between resistance to contact and clinging (Rothman et al., 2017) in experiencing ambivalence. The risks inherent in mentoring relationships that fail or are perceived by protégés as negative are high (Helms, Arfken, \& Bellar, 2016). For this reason, understanding the effect of one's self-esteem on perceptions of negative mentoring is important. However, little research has examined the role of protégé self-evaluation in the receipt of and experience of mentoring. Cyr (1992) describes self-esteem as the pride that comes from having a sense of self-worth. Research on mentoring and self-esteem has examined it as an interpersonal outcome with mixed results (Waters, 2004; Waters, McCabe, Keillrup, \& Keillerup, 2002). Self-esteem is related to relational experiences; those with high self-esteem are likely to engage in behaviors and develop cognitions that reinforce their self-concept (Korman, 1970). Individuals with high self-esteem respond less negatively to perceived failure (Dodgson \& Wood, 1998; Libby, Valenti, Pfent, \& Eibach, 2011). Thus, self-esteem will enhance the likelihood that an individual will have a positive relational experience.

Hypothesis 2: Self-esteem will be negatively related to reports of dysfunction in vocational mentoring.

\section{Dysfunction in Vocational Mentoring and Job-Related Anxiety}

In the mentoring literature, job-related stress has typically been examined as an outcome. Kram and Hall (1989) reported that mentoring might be an antidote to stress in turbulent work situations. Those who experience anxiety and uncertainty in a relationship will likely report more negative outcomes (Cassidy \& Berlin, 1994) and focus on negative emotions. Hazan and Shaver (1994) suggest that many dysfunctional relationships might be the outcome of insecure attachments characterized by feelings of discomfort. Negative feelings at work are related to negative outcomes of mentoring (Bang \& Reio, 2016). Scandura and Pellegrini (2004) discuss secure and anxious/ambivalent attachment as important for mentoring relationships. Since job-related stress may cause individuals to function in a manner that deviates from normal patterns (Jamal, 1990) it might influence negative perceptions about interpersonal relationships. Individuals may build mentoring and other supportive alliances to cope with stress at work. Stressful situations reflect work conditions in which there is pressure on the job, overwork, and limited availability of resources (Jones, Latreille, \& Sloane, 2016; Motowildo, Packard, \& Manning, 1986). Thus, the tendency to feel anxious on the job will increase the potential to report negative relational outcomes.

Hypothesis 3: Job-related anxiety will be positively related to reports of dysfunction in vocational mentoring.

\section{The Moderating Roles of Protégé Self-Esteem and Job-Related Anxiety for Dysfunction}

Self-esteem that reflects an individual difference characteristic of having high self-worth is likely to influence perceptions of mentoring. Specifically, individuals who have high self-esteem are less likely to report feeling negative emotions since they typically prefer to take control of their environment (Locke, McClear, \& Knight, 1996).

Research has indicated that protégé characteristics such as a need for power and need for achievement have been found when surveying junior members in mentoring relationships (Fagenson, 1992). Protégés report that internal locus of control, high self-monitoring, and high emotional stability enhanced their initiation of mentoring, which mediated the relationships between personality and mentoring received (Turban \& Dougherty, 1994). Turban \& Dougherty (1994) found self-esteem and negative affect represent emotional stability. Thus, self-esteem influences the amount of mentoring received through its influence on protégé attempts to initiate mentoring relationships. Self-esteem may also influence the development of the mentor relationship when negative perceptions emerge (Underhill, 2006). Self-esteem is likely to affect perceptions about relationship development since individuals with high self-esteem will view a challenge as an opportunity to learn or improve while a low self-esteem individual will view it as undeserved or a 
chance to fail (Locke, McClear \& Knight, 1996; Libby et al., 2011). We, therefore, expect that protégé selfesteem will moderate the relationship between vocational support and negative mentoring experiences.

Hypothesis 4: The relationship between reports of vocational support in mentorship and reports of dysfunction in vocational mentoring will be moderated by protégé self-esteem such that the negative relationship between vocational support and dysfunction in vocational mentoring will be weaker for those with low self-esteem.

While protégés in high-quality mentoring relationships may receive social support that can alleviate stress, individuals who tend to feel anxious in work situations may be more likely to experience dysfunction when a career-oriented mentoring relationship becomes negative. Positive attachments provide social support in times of stress and socialize participants to new, more positive behaviors (Nelson \& Quick, 1991). The extent to which an individual tends to feel anxious is likely to frame the experience of dysfunction because those who experience job-related anxiety may report more negative outcomes (Bang \& Reio, 2016).

Vocational mentoring is highly valent to career outcomes such as salary and promotions, which may raise the level of anxiety experienced by the protégé. Individuals lacking social support may concentrate on their own anxiety and insecurity (Waters, 2004). Thus, because anxiety reflects negative affect we would expect protégés that tend to feel anxious on the job to be more likely to take a negative view of relationship tension. Those experiencing more job-related anxiety are therefore more likely to view tension as an indication that the relationship has failed (Bang \& Reio, 2016; Barrick \& Mount, 1991).

Hypothesis 5: The relationship between reports of vocational support in mentorship and reports of dysfunction in vocational mentoring will be moderated by job-related anxiety such that the negative relationship between vocational support and dysfunction in vocational mentoring will be weaker for those with high job-related anxiety.

\section{The Moderating Role of Job-Related Anxiety for Individual Outcomes}

Our research focuses on the way in which negative mentoring affects performance and career potential perceptions. Performance refers to one's ability to carry out a job. Kirchmeyer (2005) discusses the importance of career functions in providing the challenge and responsibility that are important to performance. Eby et al. (2004) reported that distancing behavior in negative mentorship predicted job withdrawal. Such withdrawal is likely to be reflected in lower work performance. Job-related stress has been linked to decreased individual productivity, performance, and depression (Beehr \& Bhagat, 1985; Edwards, Guppy, \& Cocerton, 2007; Motowildo, Packard, \& Manning, 1986).

Career expectations have been described as the extent that an individual feels that he/she is likely to advance in the organization (Allen, Eby Poteet, Lentz, \& Lima, 2004). Expectations of career success are advanced as the career support provided in mentoring provides exposure and visibility needed to learn about the organization and develop a power base through which to advance one's career (Kirchmeyer, 2005). State anxiety has been linked with occupational crisis (the feeling that one's career has reached a dead end) by Hutri and Lindeman (2002) and career decision making (Jia, Hou, Zhang, \& Xioa, 2020).

Underhill (2006) conducted a meta-analysis to examine the impact of mentoring on career outcomes and suggests that the significance of mentoring in affecting work stress is questionable and should be viewed cautiously. Job anxiety describes a work context that plays an important role in moderating the effects that relationship success has on outcomes (Parmar, 2001). Work context is important since relationships exist within the context of other individuals and the environment in which the relationship resides (Hinde, 1997).

Research suggests that stress and social support have interactive effects on work outcomes (Russell, Altamaier, \&Van Velzen, 1987; Snow, Swan, Raghavan, Connell \& Klein, 2003). House (1981) asserts that the interaction effects between social support and stress on employee responses on the job are central to the literature on social support. Where negative mentoring occurs, this reflects the absence of social 
support and more importantly the presence of a distressing relationship. Since social support may have no effect on employee outcomes in the absence of stress (House, 1981), we might expect that the same would hold for mentoring as a form of support. However, negative mentorship in combination with a stressful job environment should increase the negative effects on outcomes. Negative mentoring relationships can be detrimental to careers through negative career expectations and decreased work performance. Therefore,

Hypothesis 6: The relationship between reports of dysfunction in vocational mentoring and performance will be moderated by job-related anxiety such that the negative relationship between dysfunction in vocational mentoring and performance will be stronger for those with high job-related anxiety.

Hypothesis 7: The relationship between reports of dysfunction in vocational mentoring and career expectations will be moderated by job-related anxiety such that the negative relationship between dysfunction in vocational mentoring and career expectations will be stronger for those with high job-related anxiety.

\section{METHOD}

\section{Procedure}

A questionnaire was administered to 837 employed undergraduate and Masters in Business Administration (MBA) students at 3 universities in the southeastern United States and 1 university in the Midwest. Two hundred and ninety-eight respondents $(35.6 \%)$ were undergraduate students and the remaining 539 were graduate students. In our sample, $466(55.7 \%)$ respondents reported that they had positive mentoring experiences and $236(28 \%)$ reported that they had negative mentoring experiences. The reports on traditional mentoring elicited (in section 1) were on "... your current or most recent mentor." In order to capture mentorship described as involving positive and negative experiences, we included different sections in our survey. Section 1 contained the questions on traditional mentoring. Respondents described the relationship with "... an influential individual in your work environment who has advanced experience and knowledge and is committed to providing upward mobility and support to your career" (Scandura \& Williams, 2004). Later in the survey, we asked for reports on a "...mentoring relationship that has become negative." In the descriptive section of the survey that asked about negative mentoring, we included the following question "Is this the same person that you were referring to in section I?" The response "yes" indicated relationships that were described as positive mentorship became negative. We believe that respondents did not match their responses on the two measures because we separated the scale items to prevent them from guessing the relationship between the predictor and criterion variables (Parkhe, 1993).

\section{Sample Characteristics}

Our final sample (with background variables) included the 189 respondents who had experienced functional vocational support in mentorship and also reported negative relations (dysfunction) in the same relationship. Over sixty percent of the relationships had ended at the time respondents were surveyed. The sample was $60 \%$ male, and the average age was 28 years old. The ethnic composition was $55 \%$ White, $8 \%$ Black, 18\% Hispanic, 7\% Asian/Pacific Islander, and the remainder were reported as "Other" or not reported. Fifty-one percent of respondents were employed full time, and 55\% reported holding jobs above a first-line supervisory position; $76.9 \%$ of mentors were male, $84.6 \%$ of mentors were older than the protégé. Protégés described the mentor's race, and we categorized the answers with the following result: $75.4 \%$ were White, $4 \%$ were Black, $16.6 \%$ were Hispanic, and $4 \%$ were Asian. The average length of the mentoring relationship for our sample was 16.6 months. Information provided on the mentor's position in relation to the mentor indicated that $46.8 \%$ were the immediate supervisor, $18.1 \%$ were supervisors within the same department, $5.9 \%$ were supervisors outside the department, $8 \%$ were coworkers, $9 \%$ were in other organizations, and $12.2 \%$ were "other." 


\section{Measures}

Vocational Mentoring

Vocational mentoring was measured using the scale from Scandura and Ragins (1993). A five-point response scale ranging from $1=$ "strongly disagree" to $5=$ "strongly agree" was employed. There are six items in this scale; a sample item is "This person has placed me in important assignments." The coefficient alpha estimate of internal consistency (reliability) was .89 for this measure.

\section{Dysfunction in Vocational Mentoring}

Twelve items were created based on the Eby et al. $(2000 ; 2004)$ description of negative mentoring experiences and on Scandura's (1998) definitions of the negative aspects with good intent (Difficulty and Spoiling). Questionnaires were administered to 80 undergraduate business students at a southeastern university to assess the content adequacy of the measure (Schriesheim, Powers, Scandura, Gardiner, and Lankau, 1993). Raters assessed the extent to which each item represents psychosocial or vocational support. The data gathered for the content adequacy assessment was analyzed using exploratory factor analysis. Strong support was found for the content validity of the items. Based on the results we administered the measure as part of a larger survey on mentoring practices.

Using Scandura's (1998) typology of destructive relationships on the vocational dimension, 4 items represented dysfunction in vocational mentoring. The items characterize the spoiling dimension of dysfunction in mentoring, and we refer to the construct as dysfunction in vocational mentoring: Spoiling. A five-point response scale ranging from $1=$ "strongly disagree" to $5=$ "strongly agree" was employed. Two of the items employed describe frustration with the direction of the career (1) "This person wants me to follow in his/her footsteps, stifling my desires" and (2) "This person and I disagree on the direction of my career." These reflect vocational disconnects in the relationship. The other 2 items describe regret (3) "I regret having this person as a mentor" and (4) "I am disappointed in this relationship." These reflect distress with the mentoring received and are conceptually distinct from vocational support since they do not describe a "lack" or "absence" of support, but rather describe frustration and negative feelings about the relationship. The coefficient alpha reliability for this measure was .89 .

\section{Self-Esteem}

Rosenberg's (1965) ten-item measure of self-esteem was used. A five-point response scale ranging from $1=$ "strongly disagree" to $5=$ "strongly agree" was employed. A sample item is "I feel that I have a number of good qualities." The coefficient alpha in this sample was .84. This measure has been employed in cross-cultural research and appears to be equivalent across cultures; it is also the most widely used measure of self-esteem (Schmitt \& Allik, 2005).

\section{Job-Related Anxiety}

The typical state measure of anxiety requires respondents to indicate "how they feel right now, that is, at this moment." We adapted the Speilberger, Gorush, and Lushene (1970) measure of state anxiety to measure to tap anxiety on the job in terms of how the respondent "usually" feels on their present job because we did not capture responses while individuals were at work. The typical state measure of anxiety requires respondents to indicate "how they feel right now, that is, at this moment." This mirrors the approach of Abdel-Halim (1982) who employed the state measure of the state-trait anxiety inventory so that respondents indicated the "... extent to which each statement described how they felt in connection with their present job." This measure describes feeling nervousness, upset, tense, anxious, and worried. The state-trait anxiety manual notes that the state anxiety measure discriminates between high and low-stress situations (Spielberger et al., 1970).

The approach taken to measure job-related anxiety is appropriate to our study since we were interested in responses to the work situation and the relationship to work performance and expectations of career success. This approach is supported by research that finds that stressful events arc more accurately recalled than non-stressful events (Skowronski, Betz, Thompson, \& Shannon, 1991). A four-point response scale ranging from $1=$ "not at all" to $4=$ "very much so" was employed. Respondents indicated how they usually 
feel on their present job. Sample items are "I am tense" and "I feel upset." The coefficient alpha for this measure was .90 .

\section{Performance}

The employee rating scale (ERS) measure developed by Graen, Dansereau, and Minami (1972) was employed. The measure consists of 7 items. Respondents describe their performance in the areas of dependability, alertness, skill in dealing with people, planning, know-how and judgment, expected level of future performance, and present level of performance. A five-point response scale allowed respondents to reflect on their level of performance starting with " 1 " reflecting clearly unsatisfactory levels of performance and " 5 " reflecting outstanding performance. The coefficient alpha reliability estimate for this scale was .77.

\section{Career Expectations}

The six-item measure of perceptions of likelihood to advance in the organization was employed (Scandura \& Schriesheim, 1991). A five-point response scale ranging from 1 = "strongly disagree" to $5=$ "strongly agree" was provided to respondents. For example, a sample item asks respondents to describe their level of agreement with the statement "My career has followed a course of steady advancement." In previous research, this measure has been positively correlated with vocational support (Scandura \& Williams, 2004). The coefficient alpha reliability estimate for this scale was .74.

\section{Formal Mentoring}

We include formal mentoring as a control variable since relationships created via formal mentoring in comparison to informal mentorship might be more likely to be characterized by discontent (Eby et al., 2004; Scandura, 1998). Classification of respondents as participating in formally initiated mentorships $(\mathrm{n}=78)$ was based on the response of "formal organizational program" (coded as 1) to the question "who initiated this relationship?" Individuals who responded with "self," "mentor," or "both" (coded as 0) to this question were classified as participants in informally initiated mentorships $(\mathrm{n}=111)$.

\section{Data Analysis}

Given that the dysfunction measure is relatively new, we conducted an exploratory factor analysis (EFA) to examine its dimensionality. CFAs were employed to establish the independence of the vocational support and dysfunction in vocational mentoring measures. In all CFA analyses, sample covariances were used as input for maximum likelihood estimates using Lisrel; each item was specified as loading on only one factor, errors were uncorrelated, and latent trait factor correlations were freely estimated. Regression analysis was conducted to test the hypotheses. We included positive vocational support received as a control variable in examining the effects of negative mentoring on outcomes.

\section{RESULTS}

Means, standard deviations, and correlations for study variables are reported in Table 1. The main variables of interest were correlated with the exception of dysfunction in vocational mentoring and performance. 
TABLE 1

MEANS, STANDARD DEVIATIONS, CORRELATIONS, AND COEFFICIENT ALPHA INTERNAL CONSISTENCY RELIABILITIES

\begin{tabular}{llllllllll}
\hline Variable & Mean & $S D$ & 1 & 2 & 3 & 4 & 5 & 6 & 7 \\
\hline 1. Formal & .41 & .49 & -- & & & & & & \\
2. Vocational Support & 3.71 & .86 & $-.33^{* *}$ & $(.89)$ & & & & & \\
3. Dysfunction in & 2.20 & 1.06 & & $-.49^{* *}$ & $(.89)$ & & & & \\
Vocational Mentoring & & & $.23^{* *}$ & & & & & & \\
4. Self-Esteem & 4.12 & .68 & $-.16^{*}$ & .11 & $-.28^{* *}$ & $(.84)$ & & & \\
5. Job-Related & 2.04 & .52 & .08 & -.10 & $.29^{* *}$ & $-.54^{* *}$ & $(.90)$ & & \\
Anxiety & & & & & & & & & \\
6. Performance & 4.21 & .58 & $-.25^{* *}$ & $.15^{*}$ & $-.18^{*}$ & $.39^{* *}$ & $-.36^{* *}$ & $(.77)$ & \\
7. Career & 3.30 & .76 & $-.19^{*}$ & $.31^{* *}$ & $-.22^{* *}$ & $.19^{*}$ & $-.32^{* *}$ & $26^{* *}$ & $(.74)$ \\
Expectations & & & & & & & & & \\
\hline
\end{tabular}

Note. $\mathrm{N}=189$. Formal: informal $=0$, formal $=1$. Coefficient alpha internal consistency reliabilities are in parentheses on the diagonal.

$* \mathrm{p}<.05 ; * \mathrm{p}<.01$

The partial correlation technique to control for common method biases recommended by Lindell and Whitney (2001) recommends using a variable that can be identified as theoretically unrelated to at least one other variable in the study. Thus, any relationship between the marker variables and any other variable would be due to common method variance (Podsakoff, MacKenzie, Lee, \& Podsakoff). We selected mentor age as the marker variable since this has not been identified in mentoring research as predictive of mentoring functions received or outcomes of mentoring. Our measure of mentor age asked respondents to indicate whether the mentor was "younger in age" (coded as 0) or "older in age" (coded as 1). Our results were unchanged when this variable was partialled out.

The EFA to evaluate the dimensionality of the dysfunction in vocational mentoring measure supported one factor. The negative mentoring items all items loaded cleanly on one factor with loadings above .71. The items were also all highly correlated with each other with correlations ranging from .48 to .82 . The CFA to establish the independence of the measures of vocational support in mentoring and dysfunction in vocational mentoring compared a one-factor with a two-factor model. For the one-factor model, the degrees of freedom were 35 and chi-square of 377.64. The Root Mean Square Residual was .250 (RMSR), Goodness of Fit Index (GFI) was .70, Comparative Fit Index (CFI) was .69, and Non-Normed Fit Index was .60. Our results support the two-factor model over the one-factor model with a chi-square of 66.87 and 34 degrees of freedom, representing a change in chi-square of 310 . and change of 1 degree of freedom. The model depicting vocational support and dysfunction in vocational mentoring as independent dimensions was supported with the RMSR at .045, and GFI at .94. The CFI and NNFI were above the recommended value of .95 (at .97 and .96 respectively, Hu \& Bentler, 1999). Standardized loadings ranged from .55 to .89 .

Hypotheses 1, 2, and 3 were supported. Negative relationships for vocational support, self-esteem, and a positive relationship for anxiety with reports of dysfunction in vocational mentoring (Table 2, Step 2; Table 2 Step 3; Table 2, Step 4 respectively) were found. Hypothesis 4 was supported with the negative relationship between perceptions of vocational support and dysfunction in vocational mentoring moderated by self-esteem (see Table 2, Step 5 and Figure 1). Figure 1 depicts the moderating result with a positive relationship between vocational support and reports of dysfunction in vocational mentoring for those with low self-esteem and almost no relationship (slightly negative) under high self-esteem. Hypothesis 5 was not supported. The relationship between vocational support and dysfunction in mentoring was not moderated by job-related anxiety (Table 2, Step 5). 
TABLE 2

REGRESSION RESULTS FOR THE EFFECTS OF VOCATIONAL SUPPORT, SELF-ESTEEM, AND JOB-RELATED ANXIETY ON THE OUTCOME OF DYSFUNCTION IN VOCATIONAL MENTORING

\begin{tabular}{lccccccc}
\hline $\begin{array}{l}\text { Step and Variable } \\
\text { Added }\end{array}$ & Step 1 & Step 2 & Step 3 & Step 4 & Step 5 & $\Delta \mathrm{R}^{2}$ & $\mathrm{~F} \Delta$ \\
\hline 1. Formal & $.43^{* *}$ & .16 & .10 & .11 & .06 & .04 & $7.04^{* *}$ \\
2. Vocational Support & -- & $-.55^{* *}$ & $-.54^{* *}$ & $-.52^{* *}$ & 1.77 & .17 & $35.91^{* *}$ \\
3. Self-Esteem & -- & -- & $-.35^{* *}$ & -.19 & $1.21 \dagger$ & .05 & $11.51^{* *}$ \\
4. Job-Related Anxiety & -- & -- & -- & $.38^{* *}$ & $1.80^{*}$ & .02 & $5.48^{*}$ \\
5. Vocational Support x Self- & -- & -- & -- & -- & $.37^{*}$ & .02 & $3.44^{*}$ \\
Esteem & & & & & & & \\
Vocational Support x Job- & -- & -- & -- & -- & $-.37 \dagger$ & & \\
Related Anxiety & - & & & & &
\end{tabular}

$\dagger \mathrm{p}<.10 ; * \mathrm{p}<.05 ; * * \mathrm{p}<.01$

FIGURE 1

THE MODERATING EFFECT OF SELF-ESTEEM

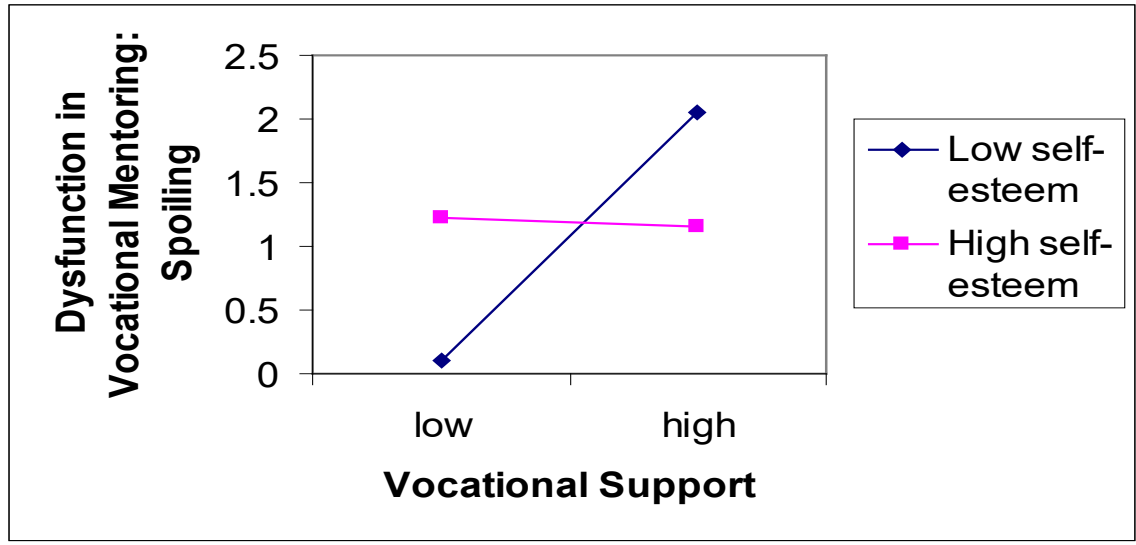

Regression analyses support Hypotheses 6 and 7. The negative relationship between perceptions of dysfunction in mentoring and performance or career expectations was moderated by job-related anxiety (see Table 3 for Performance, Step 3 and Figure 2; see Table 3 for Career Expectations, Step 3 and Figure $3)$. Figure 2 shows the moderator with a negative relationship between dysfunction in vocational mentoring and performance for those with high job-related anxiety and a positive relationship for those with low anxiety on the job. Figure 3 presents the moderator result with a negative relationship between dysfunction in vocational mentoring and career expectations for those with high job-related anxiety and no relationship for those with low anxiety on the job. 
TABLE 3

REGRESSION RESULTS FOR THE EFFECTS OF DYSFUNCTION IN MENTORING ON PERFORMANCE AND CAREER EXPECTATIONS

\begin{tabular}{|c|c|c|c|c|c|}
\hline $\begin{array}{l}\text { Step and Variable } \\
\text { Added }\end{array}$ & Step 1 & Step 2 & Step 3 & $\Delta \mathrm{R}^{2}$ & $\mathrm{~F} \Delta$ \\
\hline \multicolumn{6}{|l|}{ Dependent Variable: Performance } \\
\hline 1. Formal & $-.28 * *$ & $-.24 * *$ & $-.24 * *$ & .07 & $5.92 * *$ \\
\hline Vocational Support & .05 & .02 & .02 & & \\
\hline 2. Dysfunction in Vocational & -- & -.02 & $.38 * *$ & .13 & $13.02 * *$ \\
\hline Mentoring (DVM): Spoiling & & & & & \\
\hline Job-Related Anxiety & -- & $-.39 * *$ & .08 & & \\
\hline 3. DVM x Job-Related Anxiety & -- & -- & $-.19 *$ & .04 & $9.20 * *$ \\
\hline \multicolumn{6}{|l|}{$\begin{array}{l}\text { Dependent Variable: Career } \\
\text { Expectations }\end{array}$} \\
\hline 1. Formal & $-.20 \dagger$ & -.16 & -.16 & .10 & $8.73 * *$ \\
\hline Vocational Support & $.22 * *$ & $.19^{*}$ & $.19 *$ & & \\
\hline $\begin{array}{l}\text { 2. Dysfunction in Vocational } \\
\text { Mentoring (DVM): Spoiling }\end{array}$ & -- & -.02 & $.33 \dagger$ & .09 & $8.79 * *$ \\
\hline Job-Related Anxiety & -- & $-.41 * *$ & -.01 & & \\
\hline 3. DVM x Job-Related Anxiety & -- & -- & $-.17 *$ & .02 & $4.08 *$ \\
\hline
\end{tabular}

FIGURE 2

THE MODERATING EFFECTS OF JOB-RELATED ANXIETY

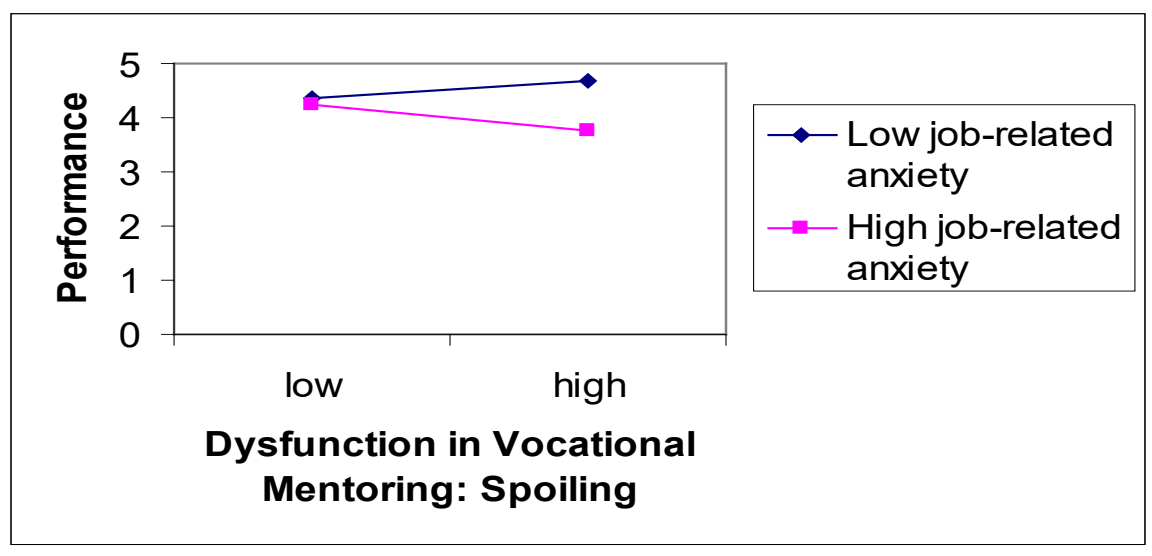




\section{FIGURE 3 \\ THE MODERATING EFFECTS OF JOB-RELATED ANXIETY}

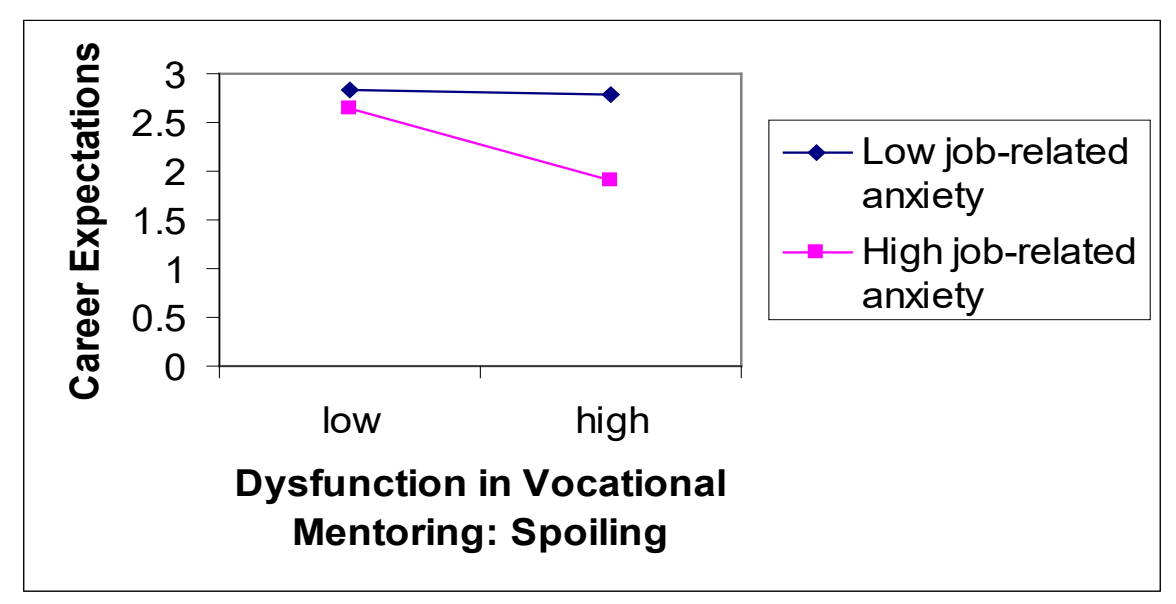

\section{DISCUSSION}

Our research supports the importance of examining the role that protégé self-evaluations and job-related anxiety play in influencing reports of negative mentoring. The moderating effects reported highlight the importance of examining the interaction between positive aspects of mentoring and self-evaluations in the experience of negative mentoring as well as the moderating role of anxious reactions to the work environment in determining work outcomes. For individuals with high self-esteem, the receipt of vocational support had little effect on the perception of dysfunction in mentoring. For individuals with low self-esteem reports of vocational support were positively related to reports of dysfunction in mentoring. Low selfesteem might result in disappointment and a stronger perception of dysfunction.

When experiencing high levels of dysfunction, individuals with low job-related anxiety appeared able to "overcome" and continue their high level of performance. Alternately, those with high job-related anxiety were significantly negatively affected by dysfunction, and the result was a negative effect on performance. A similar result was found for career expectations as the dependent variable. Thus, for individuals with high job-related anxiety dysfunction in mentoring was negatively associated with performance and career expectations. Reports of low job-related anxiety suggest that the effects of negative mentoring do not have to be detrimental. Individuals reporting low job-related anxiety showed a slight positive relationship between dysfunction in mentoring and performance, while low job-related anxiety appeared to limit the effects of dysfunction on career expectations.

Post hoc analyses found that for respondents whose negative experience of mentoring was a separate relationship $(n=47)$ the mean was 3.58 on vocational support. This difference was not statistically significant compared with a mean of 3.71 in our sample suggesting that the experience of mentorship was generally positive with the means comparable to those reported in published research presenting reports on mentorship (Allen, Eby \& Lentz, 2006). For respondents whose negative experience of mentoring was in a separate relationship, the mean was 2.78 on dysfunction in vocational mentoring (compared with 2.20 reported for our sample). This difference was statistically significant and suggests that the experience of negative mentoring differs when benefits are acquired earlier in the relationship.

\section{Implications for Theory}

The implications for mentoring theory rest with the importance of continuing to include both personality and situational variables in research on mentoring. Individuals low on self-esteem might be prone to report higher levels of dysfunction and tend to be more sensitive to negative mentoring. Research on mentoring has examined the importance of personality factors such as the Big Five (Bozionelos, 
Bozioonelos, Ploychroniou, \& Kostopoulos, 2014; Waters, 2004). As more complex models of mentoring continue to develop that push the boundaries to include new forms of mentoring (e.g., team-based, ementoring, and multiple mentoring), it will become increasingly important to include personality variables as moderators and mediators (Turban \& Dougherty, 1994) to understand the degree to which outcomes are influenced more by the quality of the relationship or the characteristics of the parties involved in the relationship (Kirchmeyer, 2005).

Research that examines the context in which mentoring occurs can move beyond comparisons of mentoring groups (e.g., formal vs. informal and supervisory vs. nonsupervisory) to include more complex variables that reflect, for example, varying degrees of support in the work context, reactions to the work context, and organizational change. Gillath and Shaver (2007) reported that negative contexts can cause participants to choose less secure behaviors (e.g., become withdrawn). It will be important to examine the attachment styles of the mentor and protégé since these likely interact to form the relationship. Scandura and Pellegrini (2004) suggest that the adult attachment styles interact to produce functional, marginal, and dysfunctional mentorship. Understanding how these attachment styles can be mitigated where they have negative implications for mentorship can help prevent the occurrence of dysfunction.

While a mentorship can become dysfunctional if the protégé has low self-esteem, the mentor might be able to compensate for this and help the protégé develop greater social competence in the workplace. Where proteges are experiencing ambivalence, it might be necessary to initiate communications with the mentor to clarify mutual expectations, resolve disagreements, or discuss areas of disappointment (Rothman et al., 2017). Research that seeks to understand interactions in mentorship will enhance our understanding of how dysfunction occurs and inform decisions to help mitigate the negative outcomes.

\section{Implications for Practice}

This research suggests that training for mentors and protégés on how to develop effective mentorships, counseling mentors and protégés on how to move past negative roadblocks in mentoring relationships and facilitate the termination of relationships that become negative may mitigate dysfunction (Scandura $\&$ Ragins, 1997). Screening of mentoring participants might be especially important to produce compatible pairs. The nature of youth mentoring involves individuals with low self-esteem and high anxiety (Klaw, Rhodes, \& Fitzgerald, 2003) so mentors must be willing to provide assistance. Screening might also be useful for assessing the protégés' needs given their self-evaluations and situational anxiety.

Berkeley (1994) warns that "An inappropriate mentor, unable or unwilling to satisfy the expectations and needs of the young person is infinitely worse than no mentor at all" (p. 27). Therefore, understanding the role of the self-concept in perceptions of negative mentoring and the role of the situational context in the outcomes of negative mentoring can help researchers and practitioners attend to choosing and training mentors who will be committed to meeting expectations more than their self-interest. Protégés are likely to attach in relationships based on a developed self-concept and reactions to stress. They differ in the degree of interdependence and dependence they experience in mentorship and thus, understanding the effects of self-esteem and situational anxiety is useful for designing mentoring interactions. While workplace mentoring is often informal, youth mentoring interventions are often formal programs designed by trained individuals hoping to transform young lives. Helping to create matches that become functional may require constant monitoring of perceived outcomes. Soucy and Larose (2000) reported that a perception of a secure relationship with a mentor was predictive of adolescent adjustment. Since youth mentoring often occurs during stressful events (Klaw, Rhodes, \& F'itzgerald, 2003), it is important to provide training with a clear focus (Welsh \& Dixon, 2016).

Our results suggest that the mentor might need to try to build positive attachments to evoke feelings of security even in protégés with low self-esteem. Open communication that clarifies mentor and protégé expectations might allow both parties to have a better understanding of the commitment needed to the relationship to fulfill each party's attachment need (Scandura \& Pellegrini, 2004). The implications of this research suggest that protégés who experience high job-related anxiety appear to need social support or secure attachments to cope with negative situations (Russell, Altmaier, \& Van Velzen, 1997; Bushman \& 
Holt-Lunstad, 2009). Our results suggest individuals who handle stress well appear able to overcome relational distress in mentoring.

\section{Study Limitations and Directions for Future Research}

The cross-sectional nature of the current study limits the conclusions that can be drawn. Since this was not a longitudinal study, we could not posit causal hypotheses in the current research. While we asked respondents to indicate whether the mentoring relationship became negative, our findings are dependent upon retrospective accounts. It is, however, encouraging to note that less than half of those with mentoring relationships reported having had a negative experience. It is interesting that over eighty percent of those that were described as negative mentorship provided earlier benefits.

We are limited in the conclusions that can be drawn about the process through which dysfunction occurred. The extent to which self-esteem is reflective of the level of neuroticism characteristic of a protégé might suggest that individuals with low self-esteem necessarily exhibit neurotic tendencies and therefore may be more sensitive to negative mentorship. Thus, future research should examine a range of indicators of protégé and mentor personality in assessing the role of individual differences in the occurrence of dysfunction in mentorship. It is also important to acknowledge that personality disorders such as those described in the Diagnostic and Statistical Manual of Mental Disorders (DSM-IV: American Psychiatric Association, 1994) might manifest themselves in dysfunctional interpersonal relationships. In our sample, we assumed that the participants were all free of psychological impairments in their descriptions of mentorship. Some disorders relevant to research on relationship quality include depression, generalized anxiety disorder, and social phobia. While it might be difficult to determine the source of problems in a mentorship where a disorder is present, problems in a mentorship may reflect the personality disorder rather than poor or dysfunctional mentoring provided.

Since we were mainly interested in examining the self-concept in relation to negative mentoring and did not include other personality measures in our survey, this limits some of our conclusions. We were, however, able to capture how self-evaluations affected the perceptions of the relationship as well as the way the situational context as it related to job anxiety affected outcomes of relational problems. We suggest that future research continue to examine the importance of individual characteristics in the development of mentoring relationships because the quality of the relationship is an outcome related to the traits of mentors and protégés and possible from the interaction of mentor-protégé traits. Our results suggest that future research can also consider the role of mediators in the prediction of mentorship dysfunction. It appears that job-related anxiety might mediate the relationship between self-esteem and dysfunction. Longitudinal research might investigate the causality of personality and work context variables in predicting problems in mentoring relationships.

We recognize that the measurement of anxiety in the current study is not identical to that presented in the state-trait anxiety manual. Our measurement reflects the tendency to be anxious in the work context. While the approach employed is similar to that used for research on work stress (Bang \& Reio, 2016; Motowildo et al., 1986), the validation of this approach requires future research that operationalizes anxiety in a similar way with a variety of populations and tests its convergence or discrimination from the state and trait measures of anxiety. The measure of dysfunction in mentoring employed in this study was developed using mentoring theory and early content validity examination. Tests of construct validity provided preliminary evidence of convergent and discriminate validity (Scandura, 1998). However, more work is needed to establish construct validity.

The use of self-reports limits the conclusions that can be drawn since common method variance might influence our results. Future research should include supervisory or objective measures of performance. Our selection of respondents with positive and negative mentoring experiences in the same relationship limits the generalizability of our results. However, we were able to control for the effects of positive mentoring while examining the effects of negative mentoring on outcomes. The pattern of significant interaction terms reported suggests that results are unlikely to have resulted from single-source bias (Kotabe, Martin, \& Domoto, 2003). 


\section{CONCLUSION}

Research, such as that by Hall (2002) and He, Walker, Payne, \& Miner, (2020), has noted the importance of relational health in employee satisfaction and productivity. Research that examines the mentoring continuum and the phases during which relationships are likely to become marginal and deteriorate might examine the separation and termination phases of mentorship and suggest approaches that can help these relationships to transition in a positive manner. We hope the current study will encourage more research that examines how negative mentoring experiences emerge in work and other settings and stimulate propositions on alternative support mechanisms that can produce positive attitudinal and behavioral responses.

\section{REFERENCES}

Abdel-Halim, A.A. (1982). Social support and managerial affective responses to job stress. Journal of Occupational Behaviour, 3, 281-295.

Ainsworth, M.D. (1989). Attachments beyond infancy. American Psychologist, 44, 709-716.

Allen, T.D., Eby, L.T., Poteet, M.L., Lentz, E., \& Lima, L. (2004). Career Benefits Associated with Mentoring for Protégés: A Meta-Analysis. Journal of Applied Psychology, 89, 127-136.

Allen, T.D., Eby, L.T., Poteet, M.L., Lima, L., \& Lentz, E. (2004). Mentoring benefits: A meta-analysis. Journal of Applied Psychology, 89, 127-136.

Allen, T.D., Poteet, M.L., \& Burroughs, S.M. (1997). The mentor's perspective: A qualitative inquiry on future research agenda. Journal of Vocational Behavior, 51, 70-89.

Allen, T.D., Poteet, M.L., Russell, J.E, \& Dobbins, G.H. (1997). A field study of factors related to supervisors' willingness to mentor others. Journal of Vocational Behavior, 50, 1-22.

American Psychiatric Association. (1994). Diagnostic and statistical manual of mental disorders (4th ed.). Washington, DC: Author.

Barrick, M.R., \& Mount, M.K. (1991). The big five personality dimensions and job performance: A metaanalysis. Personnel Psychology, 44, 1-26.

Bang, H., \& Reio, T.G., Jr. (2017). Personal accomplishment, mentoring, and creative self-efficacy as predictors of creative work involvement: The moderating role of positive and negative affect. The Journal of Psychology, 151(2), 148-170.

Beehr, T.A., \& Bhagat, R.S. (1985). Introduction to human stress and cognition in organizations. In T.A. Beehr \& R.S. Bhagat (Eds.), Human stress and cognition in organizations: An integrated perspective (pp. 3-19). New York, NY: John Wiley \& Sons.

Berscheid, E., \& Reis, H.T. (1998). Attraction and close relationships. In D.T. Gilbert \& S.T. Fiske (Eds.), Handbook of Social Psychology (pp. 193-281). New York: McGraw-Hill.

Berkley, J.P. (1994). Young people mentoring: An employment perspective. Education and Training, 36, $27-31$.

Berman, W.H., \& Sperling, M.B. (1994). The structure and function of adult attachment. In M.B. Berman \& W.H. Sperling (Eds.), Attachment in adults: Clinical and developmental perspectives. New York: Guilford Press.

Bozionelos, N., Bozionelos, G., Polychroniou, P., \& Kostopoulos, K. (2014). Mentoring receipt and personality: Evidence for non-linear relationships. Journal of Business Research, 67(2), 171-181.

Bowlby, J. (1998). A secure base: Parent-child attachment and healthy human development. London: Routledge.

Brooks, M.E., \& Highhouse, S. (2006). Familiarity breeds ambivalence. Corporate Reputation Review, 9 , $105-113$.

Bushman, B.B., \& Holt-Lunstad, J. (2009). Understanding social relationship maintenance among friends: Why we don't end those frustrating friendships. Journal of Social and Clinical Psychology, 28(6), 749-778.

Cassidy, J., \& Berlin, L.J. (1994). The insecure/ambivalent pattern of attachment: Theory and research. Child Development, 65, 971-981. 
Copeland-Mitchell, J., Denham, S.A., \& DeMulder, E.K. (1997). Q-sort assessment of child-teacher attachment relationships and social competence in the preschool. Early Education and Development, 8, 27-39.

Costa, P.T., Jr., McCrae, R.R., \& Dye, D.A. (1991). Facet scales for agreeableness and conscientiousness: A revision of the NEO Personality Inventory. Personality and Individual Differences, 12, 887898.

Cotterell, J.L. (1992). The relation of attachments and support to adolescent well-being and school adjustment. Journal of Adolescent Research, 7, 28-42.

Cyr, R. (1992). Maintaining employee self-esteem. Supervisory Management, 37, 1-3.

de Janasz, S.C., \& Sullivan, S.E. (2004). Multiple mentoring in academe: Developing the professorial network. Journal of Vocational Behavior, 64, 263-283.

Dodgson P.G., \& Wood, J.V. (1995). Self-esteem and the cognitive accessibility of strengths and weaknesses after failure. Journal of Personality and Social Psychology, 75, 178-97.

Douglas, S.C., \& Martinko, M.J. (2001). Exploring the role of individual differences in the prediction of workplace aggression. Journal of Applied Psychology, 86, 547-559.

Dreher, G.F., \& Ash, R.A. (1990). A comparative study of mentoring among men and women in managerial, professional and technical positions. Journal of Applied Psychology, 75, 539-546.

Eby, L.T., Butts, M.M. Durley, M., \& Ragins, B.R. (2010). Are bad experiences stronger than good ones in mentoring relationships? Evidence from the protégé and mentor perspective. Journal of Vocational Behavior, 77(1), 81-92.

Eby, L.T., Durley, J.R., Evans, S.C., \& Ragins, B.R. (2008). Mentors' perceptions of negative mentoring experiences: Scale development and nomological validation. Journal of Applied Psychology, 93(2), 358-373.

Eby, L.T., Butts, M., Lockwood, A., \& Simon, S.A. (2004). Protégés' negative mentoring experiences: Construct development and nomological validation. Personnel Psychology, 57, 411-447.

Eby, L.T., \& McManus, S.E. (2004). The protégé's role in negative mentoring experiences. Journal of Vocational Behavior, 65(2), 255-275.

Eby, L., McManus, S., Simon, S.A., \& Russell, J. (2000). The protege's perspective regarding negative mentoring experiences: The development of a taxonomy. Journal of Vocational Behavior, 57, 121.

Edwards, J.A., Guppy, A., \& Cockerton, T. (2007). A longitudinal study exploring the relationships between occupational stressors, non-work stressors, and work performance. Work \& Stress, 21(2), 99-116.

Ensher, E.A., Thomas, C., \& Murphy, S.E. (2001). Comparison of traditional, step-ahead, and peer mentoring on protégés' support, satisfaction, and perceptions of career success: A social exchange perspective. Journal of Business and Psychology, 15(3), 419-438.

Fagenson, E.A. (1992). Mentoring -- Who needs it? A comparison of proteges' and nonproteges' needs for power, achievement, affiliation, and autonomy. Journal of Vocational Behavior, 41, 48-60.

Fox, S., Spector, P.E., \& Miles, D. (2001). Counterproductive work behavior (CWB) in response to job stressors and organizational justice: Some mediator and moderator tests for autonomy and emotions. Journal of Vocational Behavior, 59, 291-309.

Gillrath, O., \& Shaver, P.R. (2007). Effects of attachment style and relationship context on selection among relational strategies. Journal of Research in Personality, 41, 968-976.

Graen, G., Dansereau, F., \& Minami, T. (1972). Dysfunctional leadership styles. Organizational Behavior and Human Performance, 7, 216-236.

Haggard, D.L., Dougherty, T.W., Turban, D.B., \& Wilbanks, J.E. (2011). Who is a mentor? A review of evolving definitions and implications for research. Journal of Management, 37(1), 280-304.

Hall, D.T. (2002). Careers in and out of organizations. Thousand Oaks, CA: Sage.

Hansford, B., \& Ehrich, L.C. (2006). The principalship: How significant is mentoring? Journal of Educational Administration, 44, 36-52.

Hazan, C., \& Shaver, P.R (1987). Romantic love conceptualized as an attachment process. Journal of Personality and Social Psychology, 52, 511-524. 
Hazan, C., \& Shaver, P.R. (1994). Attachment as an organizational framework for research on close relationships. Psychological Inquiry, 5, 1-22.

He, Y., Walker, J.M., Payne, S.C., \& Miner, K.N. (2021). Explaining the negative impact of workplace incivility on work and non-work outcomes: The roles of negative rumination and organizational support. Stress and Health, 37(2), 297-309.

Helms, M.M., Arfken, D.E., \& Bellar, S. (2016). The importance of mentoring and sponsorship in women's career development. SAM Advanced Management Journal, 81(3), 4-16.

Hinde, R.A. (n.d.). Relationships: A dialectical perspective. New York NY: Psychology Press.

House, R.J. (1981). Work Stress and Social Support. New York: NY: Addison Wesley Longman Publishing Co.

Hu, L., \& Bentler, P.M. (1999). Cutoff criteria for fit indexes in covariance structure analysis: Conventional criteria versus new alternatives. Structural Equation Modeling, 6, 1-55.

Hutri, M., \& Lindeman, M. (2002). The role of stress and negative emotions in an occupational crisis. Journal of Career Development, 29, 19-36.

Jamal, M. (1990). Relationship of job stress and Type-A behavior to employees' job satisfaction, organizational commitment, psychosomatic health problems, and turnover motivation. Human Relations, 43, 727-738.

Jia, Y., Hou, Z.J., Zhang, H., \& Xiao, Y. (2020). Future Time Perspective, Career Adaptability, Anxiety, and Career Decision-Making Difficulty: Exploring Mediations and Moderations. Journal of Career Development.

Jones-Brown, D.D., \& Henriques, A.W. (1997). Promises and pitfalls of mentoring as a juvenile justice strategy. Social Justice, 24, 212-233.

Judge, T.A., \& Bono, J.E. (2001). Relationship of core self-evaluation traits - self-esteem. Generalized self-efficacy, locus of control, and emotional stability - with job satisfaction and job performance: A meta-analysis. Journal of Applied Psychology, 86, 80-92.

Judge, T.A., Locke, E.A., Durham, C.C., \& Kluger, A.N. (1998). Dispositional effects on job and life satisfaction: The role of core evaluations. Journal of Applied Psychology, 83, 17-34.

Kahn, W.A., \& Kram, K.E. (1994). Authority at work: internal models and their organizational consequences. Academy of Management Review, 19, 17-50.

Kirchmeyer, C. (2005). The effects of mentoring on academic careers over time: Testing performance and political perspectives. Human Relations, 58, 637-660.

Klaw, E.L., Rhodes, J.E., \& Fitzgerald L.F. (2003). Natural mentors in the lives of African American adolescent mothers: Tracking relationships over time. Journal of Youth and Adolescence, 32, $223-233$.

Korman, A.K. (1970). Toward a hypothesis of work behavior. Journal of Applied Psychology, 54, 30-41.

Kotabe, M., Martin, X., \& Domoto, H. (2003). Gaining from vertical partnerships: Knowledge transfer, relationship duration, and supplier performance improvement in the U.S. and Japanese automotive industries. Strategic Management Journal, 24, 293-316.

Kram, K.E. (1983). Phases of the mentoring relationship. Academy of Management Journal, 26, 608-625.

Kram, K.E. (1985). Mentoring at work: Developmental relationships in organizational life. Glenview, IL: Scott Foresman.

Kram, K.E., \& Hall, D.T. (1989). Mentoring as an antidote to stress during corporate trauma. Human Resource Management, 28, 493-510.

Lee, A., Thomas, G., Martin, R., Guillaume, Y., \& Marstand, A.F. (2019). Beyond relationship quality: The role of leader-member exchange importance in leader-follower dyads. Journal of Occupational and Organizational Psychology, 92(4), 736-763.

Libby, L.K., Valenti, G., Pfent, A., \& Eibach, R.P. (2011). Seeing failure in your life: Imagery perspective determines whether self-esteem shapes reactions to recalled and imagined failure. Journal of Personality and Social Psychology, 101(6), 1157-1173.

Lindell, M.K., \& Whitney, D.J. (2001). Accounting for common method variance in cross-sectional designs. Journal of Applied Psychology, 86, 114-121. 
Locke, E.A., McClear, K., \& Knight, D. (1996). Self-esteem and work. International Review of Industrial/Organizational Psychology, 11, 1-32.

Malone, R.J. (2001). Principal mentoring. ERIC Clearinghouse on Educational Management, Eugene, or, ERIC Document No. ED 457535.

Margolis, B.K., \& Kroes, W.H. (1974). Occupational stress and strain. In A. McClean (Ed.), Occupational Stress (pp. 15-20). Springfield, Ill: Thomas.

McClure, M.J., Bartz, J.A., \& Lydon, J.E. (2013). Uncovering and overcoming ambivalence: The role of chronic and contextually activated attachment in two-person social dilemmas. Journal of Personality, 81(1), 103-117.

Mikulincer, M., Shaver, P.R., Bar-On, N., \& Ein-Dor, T. (2010). The pushes and pulls of close relationships: Attachment insecurities and relational ambivalence. Journal of Personality and Social Psychology, 98(3), 450-468.

Motowildo, S.J., Packard, J.S., \& Manning, M.R. (1986). Occupational stress: Its causes and consequences for job performance. Journal of Applied Psychology, 71, 618-629.

Nelson, D.L., \& Quick, J.C. (1991). Social support and newcomer adjustment in organizations: Attachment theory at work? Journal of Organizational Behavior, 12, 543-554.

Neustadt, E., Chamorro-Premuzic, T., \& Furnham, A. (2006). The Relationship Between Personality Traits, Self-Esteem, and Attachment at Work. Journal of Individual Differences, 27, 208-217.

Oglensky, B.D. (2008). The ambivalent dynamics of loyalty in mentorship. Human Relations, 61(3), 419448.

Parker, D.F., \& DeCotiis, T.A. (1983). Organizational determinants of job stress. Organizational Behavior and Human Performance, 32, 160-177.

Parkhe, A. (1993). Strategic alliance structuring: A game theoretic and transaction cost examination of inter-firm cooperation. Academy of Management Journal, 36, 794-829.

Parmar, N.R. (2001). Job anxiety as a moderator variable in the relationship between job characteristics and individual outcomes. Journal of the Indian Academy of Applied Psychology, 27, 75-81.

Podsakoff, P.M., MacKenzie, S.B., Lee, J., \& Podsakoff, N.P. (2003). Common method biases in behavioral research: A critical review of the literature and recommended remedies. Journal of Applied Psychology, 88, 879-903.

Raffety, B.D., Smith, R.E., \& Ptacek, J.T. (1997). Facilitating and debilitating trait anxiety, situational anxiety, and coping with an anticipated stressor: A process analysis. Journal of Personality and Social Psychology, 72, 892-906.

Ragins, B.R. (1997). Antecedents of diversified mentoring relationships. Journal of Vocational Behavior, $51,90-109$.

Ragins, B.R., \& Scandura, T.A. (1997). The way we were: Gender and the termination of mentoring relationships. Journal of Applied Psychology, 82, 945-953.

Ragins, B.R. (2016). From the ordinary to the extraordinary: High-quality mentoring relationships at work. Organizational Dynamics, 45(3), 228-244.

Rosenberg, M. (1965). Society and the adolescent self-image. Princeton, NJ: Princeton University Press.

Rothman, N.B., Pratt, M.G., Rees, L., \& Vogus, T.J. (2017). Understanding the dual nature of ambivalence: Why and when ambivalence leads to good and bad outcomes. Academy of Management Annals, 11(1), 33-72.

Russlee, D.W., Altamaier, D., \& Van Velzen, D. (1987). Job-related stress, social support, and burnout among classroom teachers. Journal of Applied Psychology, 72, 269-274.

Scandura, T.A., Graen, G.B, \& Novak, M.A. (1986). When managers decide not to decide autocratically: An investigation of leader-member exchange and decision influence. Journal of Applied Psychology, 71, 579-584.

Scandura, T.A. (1998). Dysfunctional mentoring relationships and outcomes. Journal of Management, 24, $449-467$.

Scandura, T.A., \& Pellegrini, E. (2004). Competencies of building the developmental relationship. In D. Clutterback \& G. Lane (Eds.), The situational mentor: An international review of competencies and capabilities in mentoring (pp. 83-93). Hants, England: Gower Publishing limited. 
Scandura, T.A., \& Ragins, B.R. (1993). The effects of sex and gender role orientation on mentorship in male-dominated occupations. Journal of Vocational Behavior, 43, 251-265.

Scandura, T.A., \& Schriesheim, C.A. (1991). Effects of structural characteristics of mentoring dyads on protégé outcomes. Proceedings of the Southern Management Association meeting (pp. 206-208). Atlanta, GA.

Scandura, T.A., \& Williams, E.A. (2004). Mentoring and transformational leadership: The role of supervisory career mentoring. Journal of Vocational Behavior, 65, 448-468.

Schmitt, D.P., \& Allik, J. (2005). Simultaneous Administration of the Rosenberg Self-Esteem Scale in 53 Nations: Exploring the Universal and Culture-Specific Features of Global Self-Esteem. Journal of Personality and Social Psychology, 89, 623-642.

Schriesheim, C.A., Powers, K.J., Scandura, T.A., Gardiner, C.C., \& Lankau, M.J. (1993). Improving construct measurement in management research: Comments and a quantitative approach for assessing the theoretical content adequacy, of paper-and-pencil survey-type instruments. Journal of Management, 19, 385-417.

Skowronski, J.J., Betz, A.L., Thompson, C.P., \& Shannon, L. (1991). Social memory in everyday life: Recall of self-events and other-events. Journal of Personality and Social Psychology, 60(6), 831843.

Snow, D.L., Swan, S.C., Raghavan, C., Connell, C.M., \& Klein, I. (2003). The relationship of work stressors, coping and social support to psychological symptoms among female secretarial employees. Work \& Stress, 17, 241-263.

Soucy, N., \& Larose, S. (2000). Attachment and control in family and mentoring contexts as determinants of adolescent adjustment at college. Journal of Family Psychology, 14, 125-143.

Speilberger, C.D., Gorush, R.L., \& Lushene, R.E. (1970). Manual for the State-Trait Anxiety Inventory. Palo Alto, CA: Consulting Psychologists Press.

Tong, C., \& Kram, K.E. (2013). The efficacy of mentoring-the benefits for mentees, mentors, and organizations. In Passmore, Peterson, \& Greire (Eds.), The Wiley-Blackwell handbook of the psychology of coaching and mentoring (pp. 217-242).

Turban, D.B., \& Dougherty, T.W. (1994). Role of protege personality in receipt of mentoring and career success. Academy of Management Journal, 37, 688-702.

Underhill, C. (2006). The effectiveness of mentoring programs in corporate settings: A meta-analytical review of the literature. Journal of Vocational Behavior, 68, 292-307.

Viator, R.E., \& Pasewark, W.R. (2005). Mentorship separation tension in the accounting profession: The consequences of delayed structural separation. Accounting Organizations and Society, 30, 371387.

Wanberg, C.R., Kammermeyer, J., \& Marchese, M. (2006). Mentor and protégé predictors and outcomes of mentoring in a formal mentoring program. Journal of Vocational Behavior, 69, 410-423.

Waters, L. (2004). Protégé-mentor agreement about the provision of psychosocial support: The mentoring relationship, personality, and workload. Journal of Vocational Behavior, 65, 519-532.

Waters, L., McCabe, M., Keillerup, D., \& Keillerup, S. (2002). The role of formal mentoring on business success and self-esteem in participants of a new business start-up program. Journal of Business and Psychology, 17, 107-121.

Welsh, E.T., \& Dixon, P.M. (2016). Improving mentoring outcomes: Examining factors outside the relationship. Journal of Managerial Issues, pp. 231-247.

Wood, J.T., \& Duck, S. (1995). Off the beaten track: New shores for relationship research. In J.T. Wood \& S. Duck (Eds.), Understudied relationships: Off the beaten track (pp. 1-21). Thousand Oaks, CA: Sage. 